\title{
Determinants of Voluntary Human Capital Information Disclosure: Evidence from Deposit Money Banks in Nigeria
}

\section{Nnachi Egwu Onuoha, Gregory Onuora Okoye}

To Link this Article: http://dx.doi.org/10.6007/IJARAFMS/v12-i1/12096 DOI:10.6007/IJARAFMS /v12-i1/12096

Received: 10 November 2021, Revised: 19 December 2021, Accepted: 25 December 2021

Published Online: 22 January 2022

In-Text Citation: (Onuoha \& Okoye, 2022)

To Cite this Article: Onuoha, N. E., \& Okoye, G. O. (2022). Determinants of Voluntary Human Capital Information Disclosure: Evidence from Deposit Money Banks in Nigeria. International Journal of Academic Research in Accounting Finance and Management Sciences, 12(1), 144-154.

Copyright: (c) 2022 The Author(s)

Published by Human Resource Management Academic Research Society (www.hrmars.com)

This article is published under the Creative Commons Attribution (CC BY 4.0) license. Anyone may reproduce, distribute, translate and create derivative works of this article (for both commercial and non-commercial purposes), subject to full attribution to the original publication and authors. The full terms of this license may be seen at: http://creativecommons.org/licences/by/4.0/legalcode

Vol. 12, No. 1, 2022, Pg. 144 - 154

Full Terms \& Conditions of access and use can be found at http://hrmars.com/index.php/pages/detail/publication-ethics 


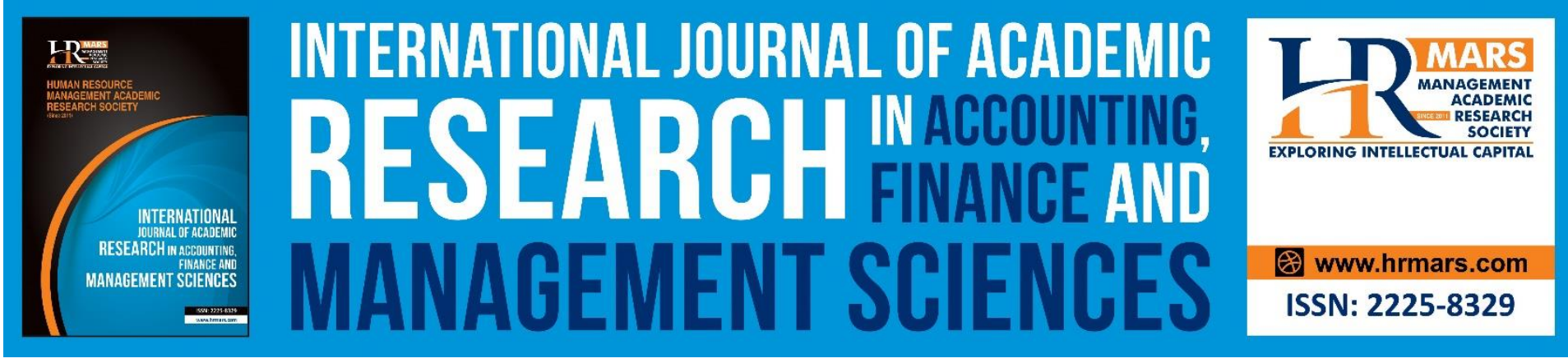

\title{
Determinants of Voluntary Human Capital Information Disclosure: Evidence from Deposit Money Banks in Nigeria
}

\author{
Nnachi Egwu Onuoha \\ Department of Accountancy/ Banking and Finance Alex-Ekwueme Federal University, Ndufu- \\ Alike, Ebonyi State, Nigeria \\ Email: ennachix@yahoo.com
}

\section{Gregory Onuora Okoye}

Department of Accountancy Madonna University, Okija, Anambra State, Nigeria

Email: Okoyegreg01@gmail.com

\begin{abstract}
Drawing on signaling and proprietary cost theories, this paper explores the drivers of voluntary human capital information disclosure. Using content analysis of the five year (From 2012 to 2016) annual reports of 12 Deposit Money Banks(DMBs)in Nigeria, a data set was collected. The data set collected was analyzed by means of Panel Corrected Standard Error (PCSE) model estimation method. The results of the analysis indicate that whereas corporate size and human capital performance have significant positive effects on the extent of human capital information disclosure, corporate profitability has insignificant positive effect on it. The study results provide an insight that would serve as a robust empirical basis for policy makers and regulators to develop human capital reporting guidelines for corporates.
\end{abstract}

Keywords: Human Capital, Human Capital Disclosure, Human Capital Information Disclosure

\section{Introduction}

The role human capital component of intellectual capital pays in any organization is very critical. As noted by Möller, Gamerschlag and Guenther (2011), one of the most important resources of any organization is human capital, but instruments of external and internal managerial reporting and controls merely slightly take it into account. However, human capital management is progressively becoming a very vital and critical part of corporate operational efficiency and managementbecause of the formation of economies that are knowledge-based around the world (Lajili \& Ze 'ghal, 2006). Moreover, the difficulty inherent in the measurement of most of the human capital indicators has engendered its underreporting. Nevertheless, companies have other possibilities or ways of reporting on its human capital and many other intangible resources, and this is normally done by means of qualitative and partially quantitative approach (Möller et al., 2011), which is often known and identified as voluntary human capital information disclosure. This voluntary human capital information disclosure, according to Aggarwal and Verma (2020), is capable of reducing 
MANAGEMENT SCIENCES

Vol. 12, No. 1, 2022, E-ISSN: 2225-8329 @ 2022 HRMARS

information lopsidedness among the numerous stakeholders. However, during the past decade and a half, human capital information reporting has received significant attention of both the practitioner and the academics across the world (Mishra \& Mishra, 2017).

Extant literature indicates rising empirical studies on the determinants of human capital information disclosure(Batista, \& Macagnan, 2013; Anifowose, Ab. rashid, \& Bin annuar, 2017; Abdul hay et al., 2018; Raimo et al., 2020). However, whereas some of the prior studies results showed that profitability is not related to human resource disclosure (Abdul hay, et al., 2018; Mishra \& Mishra, 2017; Aggarwal \& Verma, 2020), others indicated that it relates to it (see, for example, Ali and Ahmed, 2019). Similarly, while some of the studies indicated that size is positively related to human capital disclosure (Abdul hay, et al., 2018, Anifowose, et al., 2017; Möller, et al., 2011), others reported insignificant relationship amongst the variables (Mishra \& Mishra, 2017; Ali \& Ahmed, 2019; Aggarwal \& Verma, 2020). So, these study results indicate mixed or inconclusive findings.

Additionally, prior studies have explored type of auditor, liquidity, listing abroad, industry type, company age, net sales, net fixed assets, market capitalization, the debt-equity ratio, earnings per share, length of service, corporate size, profitability, total number of employees, board independence, board size, board diversity, promoter's shareholding, market capitalization and total number of pages (see, for example, Mishra \& Mishra, 2017; Abdul hay, et al., 2018; Ali \& Ahmed, 2019; Raimo, et al., 2020; Aggarwal \& Verma, 2020) as determinants of human capital information disclosure. However, none of these studies explored human capital performance as a determinant of human capital disclosure.Accordingly, this research explores:

- the effect of corporate Profitability on human capital disclosure,

- the impact of corporate size on human capital disclosure, and

- the effect of human capital performance on human capital disclosure.

Drawing evidence from twelve DMBs operating in Nigeria and analyzingthe dataset by means of Panel corrected standard error (PCSE) model estimations method, the paper results indicate that whereas profitability has insignificant positive effect on human capital disclosure, size and human capital performance have significant positive effects on human capital disclosure.

This study makes contribution in two ways. First, the paper contributes empirically by investigating human capital performance as a driver of human capital disclosure using evidence from Nigerian banking context, and thus, extends and deepens the extant body of literature on human capital disclosure. Second, this research further contributes theoretically by deploying signaling and proprietary cost theories to explain the incentive and disincentive for disclosing human capital variables in the annual reports of banks, respectively. Accordingly, both theories have further been validated as strong frameworks for offering explanation on human capital reporting behaviors of corporates.

The rest of this paper is organized as follows. While section two presents review of related literature and hypotheses development, section three details the methodological issues. Thereafter section four presents the study results. This is followed by the concluding remarks, which specifically highlights the study implications and limitations.

\section{Review of Literature and Hypotheses Development Human Capital}

Intellectual capital has been noted to be comprised of components as relational, structural and human capital (Beattie \&Thomson, 2006). Moreover, the human capital component of 
MANAGEMENT SCIENCES

Vol. 12, No. 1, 2022, E-ISSN: 2225-8329 @ 2022 HRMARS

intellectualcapital does not only consists of employees' experience and knowledge (Nonaka, 1994; Boujelbene \& Affes, 2013), but it is often regarded as the source from which innovative ability flows from (Bontis, 1998). However, the value of human capital can often be improved by any given organization through, according to Benevene and Cortini (2010), attraction from the labour market those employees that possess extraordinary skills, or doing something to ensure the development of the skills of their employees. Doing something by any organization to enhance her employees' value or skill will, according to Goldin (2014), improves the employee or individual productivity.

In addition, the intangible nature of human capital and the difficulty often encountered in measuring its variables have continued to engender its underreporting. This is because, according to Abdul Rahman (2013), although International Accounting Standard No.38 specifies accounting treatment of some intangibles resources, but this standard has many limitations in the recognition of all the components of intellectual capital, which human capital is part of. Accordingly, most corporates often engage in voluntary disclosure of the human capital variables to not only enhance the informative nature of their annual reports, but to narrow information lopsidedness. Moreover, this discretionary human capital information reporting is aimed at getting the capital market participants to be aware of it. This is because signaling theory has suggested that corporates with high quality should signal this advantage to the market (An, 2012).

Conversely, quite often, not every information concerning the human capital of any given corporate is disclosed in that company's annual report. As explained by proprietary cost theory, "the incentive to disclose information is a decreasing function of the potential proprietary costs attached to disclosure and an increasing function of the favourableness of the news in a disclosure" (Scott, 1994,p.26). So, the tendency to withhold some of the human capital information by some organizations could be to avoid some proprietary costs attaching to such disclosure. Accordingly, this study explores the drivers of voluntary human capital information disclosure.

\section{Hypotheses Development}

Existing empirical literature indicates rising studies on human capital (Alipour, 2012; Verduijn, 2013; Batista \& Macagnan, 2013; Zarei, et al., 2014; Soheyli, et al., 2014; Hejazi, et al., 2016; Anifowose et al., 2017; Abdul hay, et al., 2018; Yudawisastra, et al., 2018; Nassar, 2018; Forte, et al., 2019; Palazzi, et al., 2019; Nickolas, 2019; Raimo, et al., 2020; Tran \& Vo, 2020). Whereas some of the studies focused on human capital and corporate profitability relationship (Alipour, 2012; Verduijn, 2013; Zarei, et al., 2014; Soheyli, et al., 2014; Hejazi, et al., 2016; Yudawisastra, et al., 2018; Nassar, 2018; Forte, et al., 2019; Palazzi, et al., 2019;Tran \& Vo, 2020), others concentrated on the determinants of human capital information disclosure(Batista, \& Macagnan, 2013; Anifowose, Ab. Rashid, \& Bin Annuar, 2017; Abdul hay, et al., 2018; Raimo, et al., 2020). However, this studies on the drivers of human capital disclosure will be reviewed in the paragraphs that follow since they relate to the present study.

Abdul hay, et al (2018) investigated the determinants of human capital voluntary disclosures in the lebanese commercial banks. The authors drew data from 48 annual reports a sample of 16 commercial Lebanese banks for a period of 3 years (2015-2017) and indicated that whereas age, size and foreign ownership predicts the extent of voluntary HC disclosures, profitability and leverage do not explain the extent of $\mathrm{HC}$ disclosure commercial banks operating in Lebanese. Ali and Ahmed (2019) explored the relationship between 
MANAGEMENT SCIENCES

Vol. 12, No. 1, 2022, E-ISSN: 2225-8329 @ 2022 HRMARS

Organizational Attributes and Human Resource Disclosure drawing evidence from banks operating in Bangladeshi and indicated that while bank profitability and annual reports total page numbers has significant positive association with the level of human resource disclosure of the studied banks, the length of service, the size of the bank, and the total number of employees do not have significant effect on HR disclosure.

Anifowose, et al (2017), examined what determines the extent of human capital disclosure in the Nigerian post IFRS Regime, drawing evidence from listed firms in Nigeria stock exchange and indicated that firm's size, age and industry classification have significant positive effect on the level of human capital disclosure while profitability, the auditor type, joint audit and inherent risk have a significant negative effect on the level of disclosure. Möller, et al (2011) investigated the drivers of human capital reporting. Drawing data from 130 listed companies operating in Germany by means of content analysis, the coauthors indicated that industry membership, firm size and shareholder structure matter in the decision to report human capital. Sürdü, Özsözgün Çalıskan and Esen (2020) the determinants of Human information disclosures drawing evidence from the annual reports of the Insurance Companies operating in Turkey and indicated that number of employees, company type and foreign ownership have effects on the extent of human resource information disclosure.

Mishra and Mishra (2017) explored the association between Human Resource Disclosure and Corporate Attributes drawing evidence from service and manufacturing industries in India and indicated that whereas a significant relationship exists between promoter's shareholding and market capitalization and the extent of human capital disclosures, turnover, age, total asset and profitability do not influence the level of human capital disclosures. Drawing evidence from listed companies in India. Aggarwal and Verma (2020) investigated the relationship between Human Resource Disclosure and Company Characteristics and indicated that whereas net sales, net fixed assets, market capitalization, the debt-equity ratio, earnings per share (EPS), and total number of pages of an annual report are significantly related to human resource disclosure index, size, profitability, type of auditor, liquidity, listing abroad, industry type and company age are not significantly related to it.Similarly, Raimo, et al (2020) explored the factors that influence human capital information disclosure in integrated reports. Drawing evidence from a sample of 137 global firms, the authors indicated that whereas corporate size, board independence, board size and board diversity have significant positive effect on the extent of human capital information disclosure by the studied companies in their integrated reports, profitability has no significant effect on it

Overall, whereas someof the prior study results indicate that profitability is not related to Human Resource Disclosure (Abdul hay, et al., 2018; Mishra \& Mishra, 2017; Aggarwal \& Verma, 2020) others indicated that it relates to it (see, for example, Ali \& Ahmed, 2019). Similarly, whereas some of the studies indicated that size is positively related to Human capital Disclosure (Möller, et al., 2011; Anifowose, et al., 2017; Abdul hay, et al., 2018; Raimo, et al., 2020), others reported insignificant relationship amongst the variables (Mishra \& Mishra, 2017; Ali \& Ahmed, 2019; Aggarwal \& Verma, 2020). So, these study results indicate mixed or inconclusive findings. Accordingly, the following hypotheses are proposed:

H1: corporate Profitability has significant positive relationship with human capital disclosure. H2: corporate size has significant positive relationship withhuman capital disclosure.

Additionally, prior studies have explored type of auditor, liquidity, listing abroad, industry type, company age, net sales, net fixed assets, market capitalization, the debt-equity ratio, earnings per share, length of service, corporate size, profitability, total number of employees, 
MANAGEMENT SCIENCES

Vol. 12, No. 1, 2022, E-ISSN: 2225-8329 @ 2022 HRMARS

board independence, board size, board diversity, promoter's shareholding, market capitalization and total number of pages (see, for example, Mishra \& Mishra, 2017;Abdul hay, et al., 2018; Ali \& Ahmed, 2019; Raimo et al., 2020; Aggarwal \& Verma, 2020) as determinants of human capital information disclosure. However, none of these studies explored human capital performance as a determinant of human capital disclosure. Thus, the following hypotheses is proposed:

H3: Human capital performance has significant positive relationship with human capital disclosure.

\section{Methodology}

\section{Sample and Data Collection}

Based on availability of the annual reports DMB in their websites, twelve of these banks were selected for study. The annual reports collected covered a five year period which is from 2012 to 2016, and are international financial reporting (IFRS) compliant, since Nigerian firms adopted IFRS in 2012. The selection of DMB is because banks are knowledge intensive. Moreover, the study collects data from the annual reports by conducting content analysis following such other similar studies as Möller, et al. (2011), Abdul hay, et al.(2018), Ali and Ahmed (2019), Aggarwal and Verma (2020) and Sürdü, et al. (2020) . Consistent with Onuoha, Ofoegbu, Okafor and Onodugo (2020), a 16 items Human capital disclosure index was deployed to carry out the content analysis procedure. The data collected were assembled into dependent variables (human capital disclosure) and independent variables (Size, profitability and human capital performance indicators),

\section{Measurement Instruments}

Following presents how dependent and independent study variables were measured.

- Following Ahsan (2016), return on assets (ROA) was computed by dividing operating profit before tax by average total asset

- Human capital efficiency (HCE) was deployed to measure human capital performance and was computed by means of Pulic's model for computation of the components of Value Added Intellectual Coefficient (VAIC).

- corporate size was measured as the total assets.

- Following Onuoha, et al.(2020), human capital disclosure scores were computed as follows:

EHCD Scores $=\sum \mathrm{d} / \mathrm{M} \times 100 \%$

Where:

EHCD Scores $=$ Extent of human capital disclosure score

$\mathrm{d}=$ Number of human capital items disclosed

$M=$ Total number of human capital items that are expected to be disclosed

\section{Model Specification}

The model of this study is specified as follows:

$E H C D=a_{1}+a_{2} P+a_{3} S+H C P a_{4}+U$

Where:

EHCD = Extent of human capital disclosure scores

$\mathrm{P}=$ Corporate Profitability (proxied with Return on Asset (ROA)

$S=$ Corporate Size (proxiedtotal corporate asset) 
MANAGEMENT SCIENCES

Vol. 12, No. 1, 2022, E-ISSN: 2225-8329 @ 2022 HRMARS

$\mathrm{HCP}=$ Human capital performance (proxied with human capital efficiency)

$\mathrm{U}=$ the Error term

$\mathrm{a}_{1}=$ Intercept

$\mathrm{a}_{2}, \mathrm{a}_{3} \mathrm{and}_{\mathrm{a}} \mathrm{a}_{4}=$ coefficients of the independentvariables.

Whereas STATA version 13.0 was deployed to estimate the above model, the panel estimation method employed was panel corrected standard error (PCSE) following prior studies (see, example, Hossain, 2016; Mohammed, 2018). PCSE model is employed because, according to Hossain (2016), it has been recognized to allow contemporaneous correlation of observations amongst the panels and panel-level heteroskedasticity.

\section{Results}

The results of this study are presented descriptively and inferentially.

\section{Descriptive Analysis}

Table 1 reports the result of the descriptive analysis conducted. From this table, it would be observed that the mean of the extent of human capital disclosure is $62.42 \%$, which is well above average. This suggests that the studied DMBs in Nigeria disclose more than half of the studied human capital indicators. Specifically, the study result indicates that the studied DMBs disclose such human capital variables as employee training, employee education, average training hours, employee work-related competences, employee relationship, employee commitments and employee motivation. This disclosure may be to signal the quality of the banks' employee to the capital market. This reporting behavior supports signaling theory which, according to An (2012), states that corporates with high quality signals this advantage to the market.

Table 1 further indicates that whereas the mean of human capital efficiency (HCE) of the 12 studied DMBs is 2.711 , that of the ROA of these banks is 2.313.This suggests that on average, the average total assets of the studied banks returns itself in the form of operating profit before tax 2.3 times. Furthermore the table also indicates that the mean value of the total assets of these banks is about 2 trillion naira.

Table 1: Descriptive Statistics

\begin{tabular}{lllll}
\hline & Minimum & Maximum & Mean & $\begin{array}{l}\text { Standard } \\
\text { Deviation }\end{array}$ \\
\hline EHCD (\%) & 25 & 81.3 & 62.418 & 12.4728 \\
HCE & 1.18 & 9.05 & 2.711 & 1.54568 \\
ROA & 0.08 & 6.37 & 2.3125 & 1.51902 \\
& & & $1,916,18$ & \\
TotalAsset( A'million) & 580,226 & $4,514,788$ & 3 & $1,064,096$ \\
\hline \hline
\end{tabular}

Source: Author's Compilation from STATA (Version 13) output

\section{Inferential Analysis}

The result of the inferential analysis conducted is reported in table 2. From this table, it will be seen that corporate profitability has insignificant positive effect on human capital information disclosure $(\beta=2.96 . p>0.05)$. This result does not support hypothesis one $(\boldsymbol{H} \mathbf{1})$ which states that corporate Profitability has significant positive relationship with human 
MANAGEMENT SCIENCES

Vol. 12, No. 1, 2022, E-ISSN: 2225-8329 @ 2022 HRMARS

capital disclosure. This suggests that profitability is not an important factor to consider in the managerial decision to disclosure human capital information in corporates annual reports. This finding supports prior study findings (Mishra \& Mishra, 2017; Abdul hay, et al., 2018; Aggarwal \&Verma, 2020) that profitability is not an important factor to consider in human capital information disclosure decision making.

Table 2 further indicates that corporatesize, measured with total assets, has significant positive effect on human capital information disclosure $(\beta=0.00002$. $p<0.05)$. This result supportshypothesis two $(\mathrm{H} 2)$ which states that corporate size has significant positive relationship with human capital disclosure. This finding suggests that corporate size influence the decision to disclose human capital information variables in corporate annual reports. The study results provides further supports to prior study findings(see, for example, Möller, et al., 2011; Anifowose, et al., 2017; Abdul hay, et al., 2018; Raimo, et al., 2020) that corporate size is an important factor in human capital information disclosure decision making.

Table 2: Results of Regression Analysis

\begin{tabular}{lll}
\hline Dependent Variable & EHCD & \\
Independent Variables & Coeff. & P-Values \\
\hline HCE & 5.8264 & 0.002 \\
ROA & 2.9598 & 0.177 \\
Total Asset & 0.00002 & 0.000 \\
R-Squared & 0.8424 & \\
Wald chi2(2) & 440.2 & \\
Sig. & 0.000 & \\
\hline \hline
\end{tabular}

Source: Author's compilation from STATA (version 13)

Furthermore, Table 2 also shows that human capital performance, measured with human capital efficiency, has significant positive effect on human capital information disclosure $(\beta=$ 5.83, $\mathrm{p}<0.05)$. This result supports hypothesis three $(H 3)$ which states that human capital performance has significant positive relationship with human capital disclosure. This finding indicates that firms that have employees that are efficient in the discharge of their responsibility will like to disclose human capital information in their annual reports. Moreover, this increase in human capital information disclosure as a result of increase in human capital performance could be to signal to the capital market participants the quality of the employees of the DMBs, since such disclosure is expected to narrow the level of information asymmetry in favor of these banks. This supports the proprietary cost theory which states that "the incentive to disclose information is ... an increasing function of the favourableness of the news in a disclosure" (Scott, 1994, p.26).It further suggests that firms with superior quality will always want to signal their superior quality to the capital market, since such disclosure may be favourable to the firm. Furthermore, this result supports signaling theory which, according to An (2012), states that corporates with high quality signals this advantage to the market.

\section{Conclusion}

This paper investigates: the effect of corporate Profitability on human capital disclosure, the impact of corporate size on human capital disclosure, and the effect of human capital performance on human capital disclosure. In doing so, the paper extends and deepens 
MANAGEMENT SCIENCES

Vol. 12, No. 1, 2022, E-ISSN: 2225-8329 @ 2022 HRMARS

existing literature on human capital information disclosure. Specifically, the study results indicate that whereas profitability has insignificant positive effect on human capital disclosure, size and human capital performance have significant positive effects on human capital disclosure. These results suggest that efficient banks are wont to disclosure human capital information in their annual reports. The findings further suggest that as the sizes of banks increase the level of human capital information disclosed in their annual reports increases. Overall, the study results indicate that both size and level of efficiency of the employees are important factors that influence the decision of corporate organizations to disclose human capital information in their annual reports.

This paper has two implications. First, the findings that size and the level of human capital efficiency of the banks influence the banks' decision to report human capital information in their annual reports provide insight that would serve as strong empirical basis for policy makers and regulators to develop future human capital information reporting guidelines for banks. Second, the finding that profitability of the banks has insignificant positive relationship with the level of human capital information disclosure provides valuable insight that would help investors to understand that the level of human capital information disclosure in banks' annual reports is not driven by profitability.

The limitation of this study is in three ways. First, the study focused on DMBs operating in Nigeria. Accordingly, future studies should consider firms operating in such knowledge intensive industries as information and communication technology and insurance. Second, this study also focused on five years of adoption of international financial reporting standard which is from 2012 to 2016 . Future studies should extend this period to accommodate more years, specifically including from 2017 to 2020. Third and finally, in addition to the fact that employees' pictures were not coded, the paper concentrated on the extent of human capital disclosure. So, future empirical studies in this area should include employees' pictures as part of their human capital information disclosure index, and explore the determinants of the quality of human capital information disclosure.

\section{Significant Contributions}

This study makes contribution in three ways. First, the paper contributes empirically by investigating human capital performance as a driver of human capital disclosure using evidence from Nigerian banking context, and thus, extends and deepens the extant body of literature on human capital disclosure. Second, this research further contributes theoretically by deploying signaling and proprietary cost theories to explain the incentive and disincentive for disclosing human capital variables in the annual reports of banks, respectively. Accordingly, both theories have further been validated as strong frameworks for offering explanation on human capital reporting behaviors of corporates. Third, the insights provided by the study results would enable policy makers and regulators in Nigeria to develop human capital reporting guidelines for companies.

\section{References}

Abdulhay, D., Ragab, N. S., \& Hegazy, W. (2018). The Determinants of Human Capital Voluntary Disclosures in the Lebanese Commercial Banks. Academy of Accounting and Financial Studies Journal,22(6), 1-18.

Abdul Rahman, M. R. C. (2013). A longitudinal and cross-sectional examination of intellectual capital information disclosure in six large ftse 100 UK companies 1974-2008, doctoral dissertation, Newcastle University, Newcastle Upon Tyne. 
MANAGEMENT SCIENCES

Vol. 12, No. 1, 2022, E-ISSN: 2225-8329 @ 2022 HRMARS

An, Y. (2012). Voluntary disclosure of intellectual capital in Chinese (mainland) companies". Doctoral dissertation. Retrieved from: https://researchcommons.waikato.ac.nz/handle/10289/6581 (accessed 20 February 2017).

Ahsan, M. K. (2016). Measuring financial performance based on camel: A study on selected Islamic banks in Bangladesh. Asian Business Review, 6(13), 47-56.

Ali, M., \& Ahmed, T. (2019). Association of Organizational Attributes With Human Resource Disclosure: Evidence From Bangladeshi Banks. International Journal of Accounting and Financial Reporting, 9(2), 99-115.

Beattie, V., \& Thomson, S. J.(2006). Lifting the lid on the use of content analysis to investigate intellectual capital disclosures. Retrieved from:

https://www.hw.ac.uk/schools/img/dp2006af01.pdf, (accessed 20 August2017).

Benevene, P., \& Cortini, M. (2010). Interaction between structural capital and human capital in Italian NPOs: Leadership, organizational culture and human resource management. Journal of Intellectual Capital, 11(2), 123-139.

Boujelbene, M. A., \& Affes, H.(2013). The impact of intellectual capital disclosure on cost of equity capital:A case of French firms. Journal of Economics, Finance and Administrative Science, 18(34), 45-53.

Bontis, N. (1998). Intellectual capital: An exploratory study that develops measures and models. Management Decision, 36(2), 63-76.

Batista, F., \& Macagnan, C.B. (2013). Factors explaining the level of voluntary human capital disclosure in the Brazilian capital market. Intangible Capital, 9(1): 305321. http://dx.doi.org/10.3926/ic.315

Goldin, C. (2014). Human Capital. Retrieved from: https://scholar.harvard.edu/files/goldin/files/human_capital_handbook_of_cliometric s_0. pdf (accessed 28 November 2020).

Hossain, S. (2016). Foreign direct investment (FDI) and corruption: Is it a major hindrance for encouraging inward FDI?. African Journal of Business Management, 10(10), 256-269.

Lajili, K., \& Ze 'ghal, D. (2006). Market performance impacts of human capital disclosures. Journal of Accounting and Public Policy, 25, 171-194

Mishra, L., \& Mishra, R. (2017). Human Resource Disclosure and its Association with Corporate Attributes. Global Journal of Management and Business Research: G Interdisciplinary, $17(5), 9-18$.

Mohammed, S. D. (2018). Mandatory Social and Environmental Disclosure: A Performance Evaluation of listed Nigerian Oil and GasCompanies Pre- and Post-mandatory DisclosureRequirements. Journal of Finance and Accounting, 6(2), 56-68.

Möller, K., Gamerschlag, R., \& Guenther, F. (2011). Determinants and effects of human capital reporting and controlling. Journal of Management Control, 22, 311-333.

Nickolas, S. (2019). What is the Relationship between Human Capital and Economic Growth? Retrieved from https://www.investopedia.com/ask/answers/032415/whatrelationship-between-human-capital-and-economic-growth.asp(March 14 2021)

Nonaka, I. (1994). A dynamic theory of organizational knowledge creation. Organization Science, 5(1), 4-37.

Onuoha, N. E., Ofoegbu, G. N., Okafor, R. G., \& Onodugo, V. A. (2020). Voluntary disclosure of intellectual capital information by deposit money banks in Nigeria. Journal of Intellectual Capital, 21(6), 1035-1052. 
INTERNATIONAL JOURNAL OF ACADEMIC RESEARCH IN ACCOUNTING, FINANCE AND MANAGEMENT SCIENCES

Vol. 12, No. 1, 2022, E-ISSN: 2225-8329 ๔ 2022 HRMARS

Raimo, N., Ricciardelli, A., Rubino, M., \& Vitolla, F. (2020). Factors affecting human capital disclosure in an integrated reporting perspective. Measuring Business Excellence, 24(4), 575-592.

Scott, T. W. (1994). Incentives and disincentives for financial disclosure: voluntary disclosure of defined benefit pension plan information by Canadian Firms. The Accounting Review, 69 (1), 26-43.

Appendix

\begin{tabular}{|l|l|}
\hline SN & \multicolumn{1}{|c|}{ Human capital Indicators } \\
\hline 1 & Employee training \\
\hline 2 & Employee education \\
\hline 3 & Employee age \\
\hline 4 & Average training hours \\
\hline 5 & Management training \\
\hline 6 & Employee training hours total \\
\hline 7 & Employee productivity \\
\hline 8 & Employee work-related competences \\
\hline 9 & Entrepreneurial spirit \\
\hline 10 & Employee work-related knowledge \\
\hline 11 & Employee relationship \\
\hline 12 & Employee motivation \\
\hline 13 & Employee commitments \\
\hline 14 & Employee teamwork \\
\hline 15 & Proactive and reactive ability \\
\hline 16 & Employee health/mental state \\
\hline
\end{tabular}

Source: (Onuoha, et al., 2020) 